\title{
Lean, green practices and process innovation: a model for green supply chain performance
}

Article

Accepted Version

Creative Commons: Attribution-Noncommercial-No Derivative Works 4.0

Cherrafi, A., Garza-Reyes, J. A., Kumar, V., Mishra, N., Ghobadian, A. and Elfezazi, S. (2018) Lean, green practices and process innovation: a model for green supply chain performance. International Journal of Production Economics, 206. pp. 79-92. ISSN 0925-5273 doi:

https://doi.org/10.1016/j.ijpe.2018.09.031 Available at https://centaur.reading.ac.uk/79603/

It is advisable to refer to the publisher's version if you intend to cite from the work. See Guidance on citing.

To link to this article DOI: http://dx.doi.org/10.1016/j.ijpe.2018.09.031

Publisher: Elsevier

All outputs in CentAUR are protected by Intellectual Property Rights law, including copyright law. Copyright and IPR is retained by the creators or other copyright holders. Terms and conditions for use of this material are defined in the End User Agreement. 


\section{CentAUR}

Central Archive at the University of Reading

Reading's research outputs online 


\title{
Lean, Green Practices and Process Innovation: A Framework for Green Supply Chain Performance
}

\begin{abstract}
This paper investigates the relationship between lean, process innovation, green practices and green supply chain management performance. Data were gathered by surveying 374 firms in the manufacturing supply chain industry. Structural equation modeling (SEM) was employed to analyze the collected data. The study results show general support for the theoretical research framework. Findings reveal that there is a synergetic effect between process innovations, green and lean practices playing a crucial role towards the improvement of green supply chain performance. This paper presents an innovative approach since it studies simultaneously the three dimensions of sustainability (environmental, social and economic), the lean, the innovation process and green paradigms which are considered strategic for supply chain competitiveness. Investigation of the relationships between the four strategies is a contribution that the authors hope will become a forward step in the promotion of sustainability as a third dimension of the manufacturing supply chain, along with the efficiency and responsiveness dimensions.
\end{abstract}

Keywords: Lean; Green; Process Innovation; Green Supply Chain Performance; SEM; Survey. 


\section{Introduction}

In recent years, rapid industrial development has led to negative environmental impacts, including the over-use of resources, toxic pollutions and greenhouse gas (Peng and Lin, 2008). Global climate change has already had observable effects on the globe. It is recognized as the most significant environmental challenge facing humankind today (Dou, 2013; Van Vuuren et al., 2007; Kolk and Pinkse, 2004). In this line, the effects of climate change pressures on organizations are growing every day (Lee, 2012). As a result, the increasing concerns for the environment and social responsibility over the last few years, including pressure from customers, regulators, and other stakeholders, have led organizations to consider sustainability as part of their strategic management (Sprengel and Busch, 2011; Weinhofer and Hoffmann, 2010). For example, it has now become more common and accepted knowledge that for organizations to remain competitive, and in some cases to survive, a proper balance of economic, environmental and social priorities needs to be managed in their global operations (Cherrafi et al., 2016b). Thus, determining how to promote sustainability is currently one of the most important issues being investigated in both theory and practice (Dou, 2013).

A successful transition to sustainability depends on many factors related to the economy, society, politics, law and culture (Dou, 2013) and requires radical changes in technology, institutions, business strategies and consumption practices. As a result, companies are likely to face new challenges, especially in terms of the management of their processes and operations. This scenario requires changes in innovation practices and the deployment of new methods and approaches to improve sustainability performance not only at a company's level but also across supply chains. Firms need to extend their focus beyond internal operations to external partners in their supply chains (Martínez-Jurado and Moyano-Fuentes, 2014). In this context, lean, green and process innovation approaches have emerged as major parts of the sustainability answer to support organizations in becoming more competitive and sustainable in an ever more volatile and highly demanding market arena (Hojnik and Ruzzier, 2016; Garza-Reyes, 2015a). Several studies can be categorized under the label of "Green and Lean" (e.g. Cherrafi et al., 2016a; Garza-Reyes, 2015a), "Lean and Green Supply chain" (e.g. Carvalho et al., 2017; Martínez-Jurado et al., 2014; Hajmohammad et al., 2013), "Innovation and Supply chain" (e.g. Lee et al., 2014; Jabbour et al., 2015; Zailani et al., 2015; Lii et al., 2015; Zimmermann et al., 2016) or "Innovation and Lean" (He et al., 2015; Antony et al., 2012; ). However, no research has explored the relationship between these three concepts (i.e. 
lean, green and process innovation) and their effect on different dimensions of Green Supply Chain performance (GSC) performance.

It is clear that process innovation, green lean and supply chain sustainability have been extensively investigated but mainly treated as separated research streams, which has resulted in these subject fields being separately and independently researched from each other. This suggests the existence of a gap in our current understanding of the relationship of supply chain sustainability, lean, green and process innovation. Putting all these subjects together is a challenge and the originality of this research. In addition, the lack of a clear relationship between these practices and GSC performance is an obstacle for companies seeking to justify the implementation of GSCs. Given this situation, this study aims at proposing a conceptual framework to analyze the effect of process innovation, green, and lean practices on the performance of GSCs.

This study has significant theoretical and practical contributions. At the theoretical front, it develops a theoretical framework to study the relationship between different elements of interest for this research, namely: process innovation, lean, green practices and GSC performance. Such relationship has not been assessed in the scholarly literature and is important in clarifying the role of the three constructs regarding their effect on GSCs. At the managerial front, this research can help managers in understanding the role of different constructs on GSC performance and consequently to formulate appropriate strategies for effectively developing and/or adopting GSC practices within their organization.

The rest of the paper is structured as follows: in the following section, a literature review related to lean, process innovation, green practices and their linkage to GSC performance is presented. This is followed by the presentation of the proposed research framework and formulated hypotheses. Then, the research methodology is described, and data analysis and results presented. Lastly, considerations, implications, and conclusions derived from the present research are included.

\section{Literature review and hypotheses formulation}

The objective of this literature review is to reflect on and analyze the current body of research exploring the relationship between lean, green concepts and process innovation practices, and their effects on GSC performance. First, literature exploring the individual effects of the selected practices on GSC performance will be reviewed. Second, similarities between these practices will be explored to analyze their combined effect on GSC 
performance. Based on this literature review, hypotheses will be formulated and subsequently tested in the following sections.

\subsection{The impact of Lean Management on Green Supply Chain Performance}

The concept of lean became popular through Womack and Jones' (1990) book 'The Machine That Changed the World'. Lean production has been defined in various different ways (Dahlgaard and Park, 2006). One reason for the lack of a coherent definition might be that the concept is still evolving (Hines et al., 2004). However, the main goal of a lean system is to produce products or services of higher quality at the lowest cost and in the least time by eliminating wastes (Dennis, 2007; Liker 1996). In the lean context, waste is defined as "anything other than the minimum amount of equipment, materials, parts, space and time which are absolutely essential to add value to the product" (Russell and Taylor, 2000). Seven forms of waste were identified: transport, inventory, motion, waiting, overprocessing, overproduction, and defects. All of these wastes have a direct impact on performance, quality and costs, and these are all non-value-adding operations for which customers do not want to pay. In recent decades, organizations in different economic sectors have implemented lean management (LM) and in many cases this has helped them to improve their competitiveness and their results (Belekoukias et al., 2014; Moyano-Fuentes and Sacristán-Díaz, 2012). In this context, it is important for lean practices and principles to be spread throughout the supply chain to derive the potential benefits of LM (Hajmohammad et al., 2013; Hines et al., 2004; Womack and Jones, 1996). There are evidences in literature regarding the positive impact of LM on the economic and social sustainability of supply chains. According to Fliedner and Majeske (2010), sustainability is the next evolutionary stage of lean as it goes beyond the internal waste elimination of Ohno's seven lean principles, encouraging external waste reduction across the supply chain and leading to the improvement of social conditions globally (Govindan et al., 2014c). LM can be implemented right across the whole supply chain, from the procedure to place the order with suppliers to product distribution and delivery to the customer, with the aim of reducing wastes, improving quality, increasing flexibility and customer service and reducing costs at all stages of the supply chain (MartínezJurado and Moyano-Fuentes, 2014).

The LM strategy has a positive impact on economic performance in the following way: a positive impact of the level of internal LM implementation on both suppliers and customers (So and Sun, 2010; Simpson and Power, 2005), improvements in results to be achieved in the chain as a whole (Pérez et al., 2010), business risk reduction through joint investments in 
R\&D and technology, improved product quality, reduced inventories, increased knowledge through collaborative product design or an overall reduction in wastage throughout the supply chain (Arkader, 2001; Hines, 1996). In the same way, LM is important for achieving environmental sustainability across the supply chain and, ultimately, all the potential benefits of the Green Supply Chain strategy (Dües et al., 2013; Mollenkopf et al., 2010). Thus, LM impacts on environmental sustainability in the following way: close and long-term relationships trigger the adoption of environmental management practices (Florida, 1996), some practices and tools, such as lean supplier development and value stream mapping, could be useful for adopting environmental management practices (Mason et al., 2008; Simpson and Power, 2005), collaborative design from the very first stages of product development impacts on environmental design to reduce environmental pollution throughout all stages of a product's life cycle (e.g., closed-loop supply chain) (Carvalho et al. 2017; Carvalho et al., 2011). Other positive results that come out of the synergy between the lean and Green Supply Chain Management strategies are reductions in inventory levels, excess capacity, and transport and production times, and increased levels of integration and frequency of information sharing throughout the supply chain (Carvalho et al. 2017; Carvalho et al., 2011). From this perspective, the following hypothesis is formulated:

\section{$H_{1}:$ LM has a positive effect on Green Supply Chain performance}

\subsection{The impact of Green practices on Green Supply Chain Performance}

In recent times, changes in the business environment, including increasing environmental awareness, pressure from customers, legal requirements, the need for waste management, product recovery, reuse of materials and packaging, and changes in product projects, have influenced supply chain management. Thus, organizations have been forced to make their operations greener and more sustainable by adopting initiatives that take into consideration the environmental impacts of their processes, services and products (Vinodh et al. 2016; Lucato et al. 2015; Garza-Reyes, 2015a). In this line, green practices have emerged as a new philosophy to help organizations to improve their environmental performance while still achieving their economic objectives (Cherrafi et al., 2016a; Garza-Reyes, 2016b).

In a literature review conducted by Srivastava (2007) about GSCs, green practices were classified into three groups: green design (eco-design and life cycle assessment), green operations (green manufacturing and remanufacturing), reverse logistics and waste 
management. This classification was selected to delimit the present study because the first was a compilation of the most often described practices in the literature. According to Jayal et al. (2010), efforts to make manufacturing more sustainable must take into consideration the product, process and systems perspectives. At the process level, occupational hazards, resource and energy consumption, and toxic wastes need to be minimized. At the system level, all aspects of the entire supply chain need to be considered, taking into account all of the major life cycle stages-pre-manufacturing, manufacturing, use and post-use-over multiple life cycles.

The impact of green practices on supply management performance has been the topic of several studies (Vachon and Klassen, 2006; Zhu and Sarkis, 2004). This impact may include economic, environmental and social performance. Various researchers have provided empirical evidence to support the linkage between the adoption of green practices within a firm or across its supply chain and its environmental and social performances. Vinodh et al. (2011) argue that the adoption of green practices in supply chains can have a positive impact on sustainability; one example is related to Ford, where this company had implemented recyclable plastic containers for shipping their car parts as opposed to cardboard, reducing $\mathrm{CO} 2$ emissions during transportation, improving process efficiency since new containers were handled easily by plant workers, and reducing transportation cost by over $25 \%$. According to Scur and Barbosa (2017), leading manufacturers generally implement green practices and have high levels of environmental and social performance including improved environment; better compliance with environmental regulations; more cohesive working environment for laborers and; better public image of the organization (Halme et al., 2002). Moreover, the implementation of green practices offers many significant economic benefits (Dubey et al., 2015; Lee et al., 2014; Govindan et al., 2014b, 2015), which presents a "win-win" situation for firms and the environment (Beckmann et al., 2014). Green practices can reduce material and production costs, reduce transportation and logistics cost, increase product quality, reduce warehouse cost, and even increase innovativeness (Pagell and Gobeli, 2009; Svensson, 2007, Pagell et al., 2004; Christmann, 2000; Russo and Fouts, 1997). These practices enhance resource efficiency which relates directly to economic performance (Zhang et al., 2012). Rao and Holt (2005) demonstrated a positive relationship between green practices and the economic performance of supply chains. They also found that GSCM practices led to competitiveness and better economic performance. However, there is a need for more 
research in this area to ascertain how green practices interact with different performances of the GSCs. Consequently, the following hypothesis is formulated:

\section{$\mathrm{H}_{2}$ : Green practices have a positive effect on Green Supply Chain performance}

\subsection{The impact of Process Innovation on Green Supply Chain Performance}

Over the past few decades, rapid changes in the business arena and globalization have forced organizations, regardless of their size; to adopt innovation to face the dynamic uncertainty and intense competition posed by such business environment (Pan and Li, 2016). Innovation has thus become vital to organizations' growth and survival (Hojnik and Ruzzier, 2016). The literature on innovation distinguishes between different types of innovation, for example, process innovation and product innovation. The present study pertains to process innovation, which refers to new elements (e.g. new production methods, management approaches and new technologies) introduced into organizations' management and production operations (Brem et al., 2016; Salerno et al., 2015). It involves the use of new knowledge, tools and devices inputs that can help organizations to reconfigure, exploit and maximize resources and capabilities in order to reduce costs and enhances production efficiency (Salerno et al., 2015). Process innovation may possibly be translated into investment in new technology embodied in equipment and machinery, new software for supply-chain management, new software for designing products and training of staff to offer new services to customers, etc. (Pan and Li, 2016).

It should be noted that with increasing environmental concerns, we have noted the emergence of a new field of process innovation called green process innovation, which aims at modifying manufacturing systems and processes in order to reduce environmental impacts, pollution, and other negative effects on the use of resources (Wong et al., 2013; Kammerer, 2009; Meeus and Edquist, 2006). Previous empirical research suggests that process innovation improves various aspects of firms' performance (Lau et al., 2010; Lambertini and Mantovani, 2009). Specifically, it can improve customer satisfaction, operational performance, and also financial performance. Chen et al. (2006) found that the implementation of process innovation delivered positive outcomes - the more the firms invested in process innovation, the stronger was their competitive advantage. Similarly, Chiou et al. (2011) found that process innovation is positively related to a firm's competitive advantage. Companies implement process innovation in manufacturing processes to shorten production time and reduce costs 
(Lambertini and Mantovani, 2009). More recently, Hojnik and Ruzzier (2016) found that process innovation is worthwhile in terms of company profitability, growth, and competitive benefits. According to Kleindorfer et al. (2005) process innovation can assist organizations in increasing the economic and social performance of a company through waste and cost reduction. In this context, Doran and Ryan (2012) found that organization that implement process innovation enjoy higher levels of revenue per employee than organizations that do not introduce process innovation. In addition, process innovation demonstrates a positive impact on the increase in the number of employees and turnover (Rennings et al., 2006). Moreover, firms that apply process innovation do not only improve market position, resolve difficulties and increase competitive advantages, but also improve corporate image, leapfrogs competition and creates breakthroughs (Presley et al., 2007; Mu et al., 2009).

With the increasing environmental concerns, organization could also adopt green process innovation to reduce environmental risks, pollution, and other negative effects on resources use throughout its life cycle (Zhao \& Sun, 2016; Wong et al., 2013). According to Peng et al. (2016), green process innovation can make a substantial contribution to improve the environmental performance of organizations, which allows them to meet the stakeholders' requirements and regulatory agencies (Berrone et al., 2013; Qi et al., 2010; Murillo-Luna et al., 2008). Therefore, three performance types (i.e., economic, environmental, and social) are considered within the benefits and outcomes of process innovation. Researchers have also considered the specific impact of process innovation within a supply chain context. For example, in a survey of 153 firms in the Malaysian automotive supply chain industry, Zailani et al. (2015) found a positive effect of process innovation on simultaneous firms' economic, social, and environmental performances. In general, researchers agree that improved innovation performance cannot be achieved by the firm on its own and there is an increased need for supply-chain collaboration (Kibbelling et al., 2013; Soosay et al., 2008; Nieto and Santamaría, 2007). However, only few studies in the literature have analyzed the relationship between process innovation and green supply chain performance. For this reason, Gao et al. (2017) called for more research under the supply chain context. Since competition has moved beyond the single firm to the supply chain, and given the importance that process innovation has for the survival of organizations in the current market, the study of the impact of process innovation on green supply chain performance is of great importance. We have consequently proposed the following hypothesis: 
$H_{3}$ : Process innovation has a positive effect on Green Supply Chain performance

\subsection{Lean, Green, process innovation and Green Supply chain performance relationship}

In the supply chain context, it is important to integrate management practices that do not only improve organizational and overall supply chain performance, but also that take into consideration the economic, environmental, and social dimensions (Beske, 2012). According to Govindan et al. (2014a), supply chain management should be concerned with its sustainability. Lean, green, and process innovation are referred to as SCM paradigms which can help organizations to become more sustainable and competitive in a high and volatile market. However, no researches have simultaneously explored the three practices and their impact on green supply chain performance. The existing literature has only focused on two of these SCM paradigms (green and lean) and supply chain performance.

According to Azevedo et al. (2012a), the implementation of lean and green practices along the supply chain enables an enhanced economic, environmental, and social performance. The benefits of integrating lean and green principles include reduced lead time and costs, improved process flow, better relationships with suppliers, customers and other stakeholders, improvement of environmental quality, as well as employee morale, and commitment (Cherrafi et al., 2016a; Hajmohammad et al., 2013a; EPA, 2009). Integration of process innovation with these practices might be of greater value not only to a company's operation, but also to its supply chain. The performance of green lean supply chain can be supported and enhanced through the adoption of process innovation.

The proposed synergetic relationship between lean, green, process innovation and green supply chain performance can be supported by the resource-based view (RBV). The RBV aims to describe, explain and predict how organizations can achieve a sustainable competitive advantage by acquiring and controlling valuable, rare, inimitable and non-substitutable resources (Peteraf, 1993; Barney, 1991). Resources can be tangible (e.g. equipment) or intangible (e.g. process knowledge) assets that are key inputs of the production and delivery of products and services (Grant, 1991). A resource comes as a sustainable competitive advantage when other organizations are unable to duplicate the benefits of strategies that improve performance (Barney, 1991). Operation management systems such as lean and green viewed from a RBV perspective might not satisfy the requirements to be a source of sustainable competitive advantage. They can be substitutable and transferable across 
organizations and supply chain. The integration of process innovation with these practices will be of greater value not only for an organization's operation but also to its supply chain. Based on the RBV and previous literature, we believe that the impact of green and lean on green supply chain performance might be complemented by process innovation, resulting in a complementary performance enhancing relationship. According to Teece (1986), complementarity refers to how one resource might influence another, and how this relationship affects a firm's competitive position or performance. Consequently, we propose the following hypotheses:

$H_{4}$ : Adoption of Green practices (a) and lean management (b) have a stronger positive impact on operational green supply chain performance when combined with process innovation

Based on the conclusions and propositions derived from the literature, the following conceptual research framework is suggested to translate the relationships between lean, green, process innovation and GSC performance, see Figure 1. Green and lean are the independent variables that are suggested to improve green supply chain performance $\left(\mathrm{H}_{1}\right.$ and $\left.\mathrm{H}_{2}\right)$. Process innovation is also expected to improve green supply chain performance $\left(\mathrm{H}_{3}\right)$ and also moderate the impact of green and lean practices on performance $\left(\mathrm{H}_{4 a}\right.$ and $\left.\mathrm{H}_{4 b}\right)$. The subsequent sections report the empirical results of the testing of this framework with its associated hypotheses.

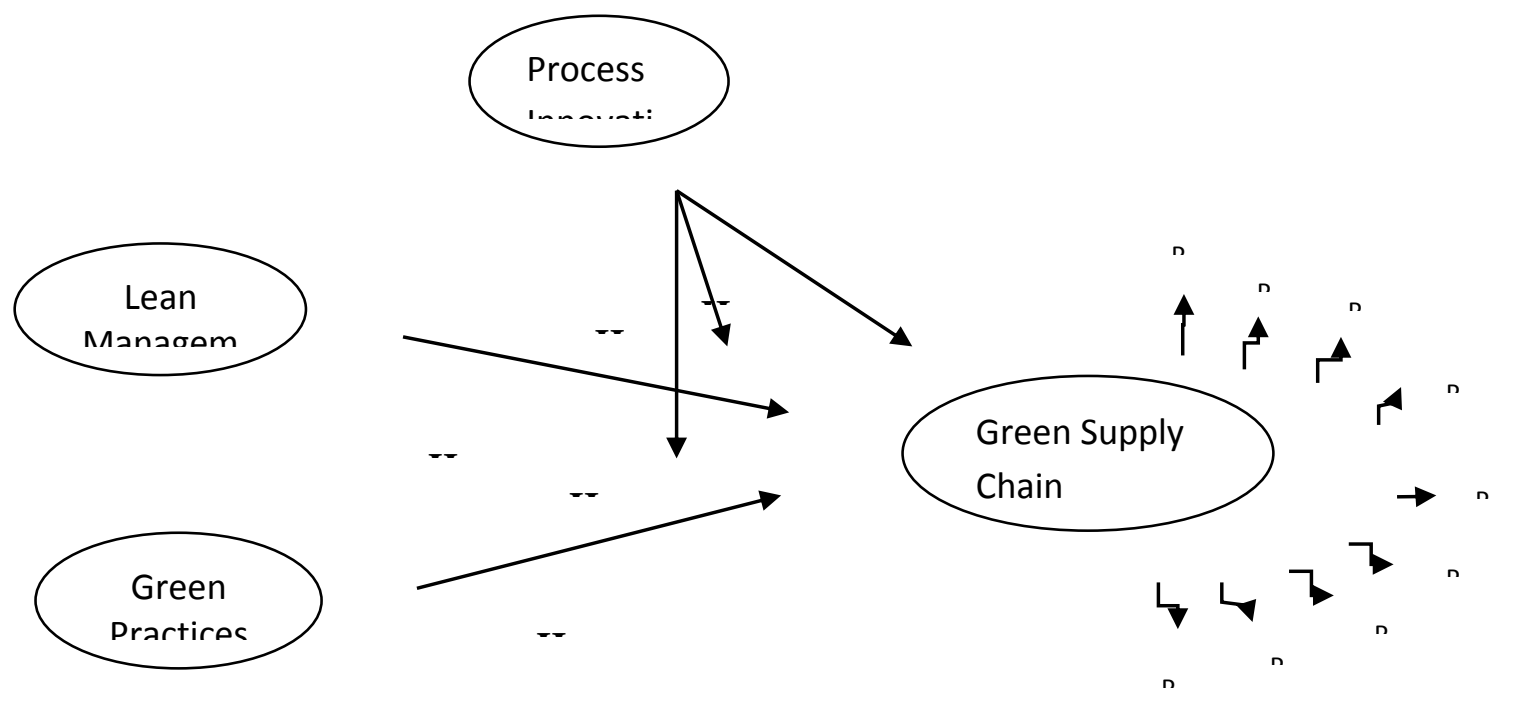

Fig.1. Research framework 


\section{Research methodology}

This research used a quantitative survey with a structured questionnaire to collect data to study the impacts of lean, green and process innovation on GSC performance. The collected data was analyzed using SPSS software version 19 (SPSS, Inc., Chicago, IL, USA). Details are addressed in following sub-sections.

\subsection{Instrument development and data collection}

Based on the literature review regarding the impact of green, lean, and process innovation on GSC performance, as well as on the conceptual research framework developed, see Figure 1, a structured questionnaire was designed to obtain quantitative data for the statistical testing of the hypotheses. The questionnaire consisted of five sections with a total of 59 items. The first section was designed to capture basic profile information and demographic details about the respondents and their organizations. The rest of the sections consisted of questions related to evaluating the impact of green, lean, and process innovation on Green Supply Chain performance. Furthermore, to avoid social desirability bias, respondents could either choose to give their email addresses and the name of the company or remain anonymous.

The items were measured by using a five-point Likert-type scale ranging from 1 (strongly disagree) to 5 (strongly agree). Further, in this study, data was collected from executive directors, engineers, manufacturing managers, production managers, operation managers, quality managers, and managing directors employed in various organizations in thirteen countries. This category of respondents is directly involved and experienced in supply chain operations and activities of their respective organizations. Before the questionnaire was mailed, it was pretested by taking feedback from three supply chain managers and two academic experts in the subject. Pretesting helped us to improve the survey and to ensure content validity. After pretesting the questionnaire, a pilot study was conducted to validate the survey instrument and its capability to obtain all the data gathering objectives of the main survey. The pilot study consisted of 20 responses, from which some modifications were made to improve the survey instrument and obtain a final draft for its subsequent distribution. The questionnaire was then sent to organizations. The targeted firms were selected by means of a simple random method, with a reliability level of $95 \%$ and a maximum error level of $\pm 5 \%$.

According to Luthra et al. (2016), the selection of the sample, and its size, are of paramount importance for achieving adequate and superior data from the questionnaire survey. In the present study, data was collected from thirteen countries. This sample frame 
provided an important source of information related to the impact of green, lean, and process innovation on GSC performance within an international context. Consequently, this sample frame can contribute in generalizing the results throughout these countries, which can be viewed as an advantage in comparison to single country studies (Onofrei et al., 2016). Table 1 shows the characteristics of the organizations that participated in the study survey in terms of country, industry, and company size. After a number of emails reminders, a total of 374 usable responses were collected to test the previously formulated hypotheses.

Table1. Characteristics of the sample

\begin{tabular}{|c|c|c|c|c|c|}
\hline Country & Frequency & Industry & Frequency & Size $^{*}$ & Frequency \\
\hline Morocco & 13 & Chemical and plastics & 22 & $<50$ & 42 \\
\hline South of Africa & 15 & Advanced manufacturing & 13 & $51-100$ & 89 \\
\hline Germany & 59 & Automotive & 114 & $101-500$ & 147 \\
\hline France & 48 & Biotechnology & 7 & $501-1000$ & 30 \\
\hline Italy & 13 & Building and construction & 42 & $>1000$ & 18 \\
\hline Spain & 29 & Food and agribusiness industry & 61 & & \\
\hline Sweden & 18 & Textile, clothing and footwear & 58 & & \\
\hline Finland & 27 & Pharmaceutical and health technologies & 19 & & \\
\hline USA & 45 & Metal and mining & 19 & & \\
\hline Austria & 31 & Other industries & 5 & & \\
\hline Brazil & 37 & \multirow{3}{*}{$\begin{array}{l}\text { Wood products and associate } \\
\text { manufacturing }\end{array}$} & \multirow{3}{*}{14} & & \\
\hline Malaysia & 23 & & & & \\
\hline India & 16 & & & & \\
\hline Total & 374 & Total & 374 & Total & 374 \\
\hline
\end{tabular}

*Number of employees

In the present study, organization size and industry were used as control variables. These variables are chosen because they have significant effects and may affect the results of the study.

\subsection{Measurement framework validation}

To check the internal reliability of the collected data, the Cronbach's alpha reliability test was performed for the questionnaire constructs. In this study, the Cronbach's alpha of all constructs was well above the recommended value of 0.7 (Nunnally, 1978), with a minimum of 0.709 , see Table 2 . These results show that the study questionnaire was in compliance with internal consistency reliability requirements. Next, a confirmatory factor analysis (CFA) was conducted by using LISREL 8.8 to examine the validity of the measurement framework. Table 2 provides an overview of the CFA results in terms of their factor loading, $t$-values, standard errors, and R2. It is also important to address incremental and absolute fit issues. A comparison of the following goodness-of-fit values against those in $\mathrm{Hu}$ and Bentler (1998) 
show that the proposed research framework was satisfactory (RMSEA=0.047; RMSEA 9 à per cent conf. interval $(0.042 ; 0.054) ; \mathrm{RMR}=0.11 ; \mathrm{GFI}=0.95 ; \mathrm{NNFI}=0.98 ; \mathrm{AGFI}=0.96$; $\mathrm{CFI}=0.98 ; \mathrm{RFI}=0.96$; $\mathrm{IFI}=0.97$ ). Moreover, the ration of chi-square to degrees of freedom of $2.83(\mathrm{x} 2 / \mathrm{df})$ was lower than the threshold of 3 required for an acceptable framework fit (Kline, 1998). Thus, it was possible to conclude that the items represented a reasonable measure of the construct under examination.

In addition, the convergent validity and discriminant validity were also evaluated at this stage to confirm the measurement framework. Convergent validity can be defined as "the degrees to which two or more items measuring the same variable agree" (Thong, 2001). Convergent validity was assessed by comparing the coefficients and the standard error of the items. As shown in Table 2, the results revealed that each coefficient was greater than to twice its associated standard error (Anderson and Gerbing, 1988). These results established convergent validity, see Table 2 , thus confirming the convergent validity of the measurement framework. Finally, discriminant validity measures "the degree to which items differentiate between variables"' (Thong, 2001). In this case, discriminant validity was examined by using intra-factor correlations. The results in Table 3 showed that inter-factor correlation was within an acceptable range. Therefore, it was concluded that the measure had adequate levels of discriminant validity.

Table 2. Construct measurements summary: Confirmatory factor analysis and scale reliability.

\begin{tabular}{|l|l|c|c|c|c|}
\hline \multicolumn{1}{|c|}{ Variable } & Loading & t-value & Std. Error & $\mathbf{R}^{\mathbf{2}}$ \\
\hline \multirow{3}{*}{$\begin{array}{l}\text { Green } \\
\text { practices } \\
\alpha=.721\end{array}$} & eco-design and life cycle assessment & 0.57 & 21.70 & 0.074 & 0.42 \\
\cline { 2 - 6 } & green manufacturing & 0.59 & 24.80 & 0.081 & 0.67 \\
\cline { 2 - 6 } & reverse logistics & 0.75 & 21.27 & 0.090 & 0.56 \\
\cline { 2 - 6 } & waste management & 0.61 & 19.16 & 0.12 & 0.62 \\
\hline \multirow{2}{*}{$\begin{array}{l}\text { Lean } \\
\text { management } \\
\alpha=.753\end{array}$} & JIT & 0.64 & 21.80 & 0.11 & 0.41 \\
\cline { 2 - 6 } & Set-up time reduction & 0.54 & 22.36 & 0.10 & 0.40 \\
\cline { 2 - 6 } & Cellular manufacturing & 0.69 & 23.69 & 0.10 & 0.50 \\
\cline { 2 - 6 } & Waste elimination & 0.51 & 21.74 & 0.11 & 0.46 \\
\hline \multirow{4}{*}{$\begin{array}{l}\text { Process } \\
\text { innovation } \\
\alpha=.714\end{array}$} & $\begin{array}{l}\text { Fast response to the new processes } \\
\text { introduced by other companies } \\
\text { within the same sector }\end{array}$ & 0.66 & 29.87 & 0.11 & 0.44 \\
\cline { 2 - 6 } & $\begin{array}{l}\text { Pioneering disposition to introduced } \\
\text { new process }\end{array}$ & 0.67 & 27.81 & 0.087 & 0.49 \\
\cline { 2 - 6 } & $\begin{array}{l}\text { Number of changes in the process } \\
\text { introduced in one year }\end{array}$ & 0.63 & 22.08 & 0.091 & 0.42 \\
\hline \multirow{3}{*}{$\begin{array}{l}\text { Green supply } \\
\text { chain } \\
\text { performance } \\
\alpha=.709\end{array}$} & economic efficiency, & 0.71 & 28.43 & 0.10 & 0.40 \\
\cline { 2 - 6 } & performance & 0.62 & 31.93 & 0.033 & 0.71 \\
\cline { 2 - 6 } & integration, & 0.76 & 25.87 & 0.3 & 0.42 \\
\cline { 2 - 6 } & collaboration & 0.60 & 29.34 & 0.092 & 0.55 \\
\cline { 2 - 6 } & partnership & 0.68 & 30.13 & 0.031 & \\
\cline { 2 - 6 } & responsiveness & 27.19 & 0.10 & 0.40 \\
\hline
\end{tabular}




\begin{tabular}{|l|l|c|c|c|c|}
\hline & cost & 0.61 & 32.17 & 0.13 & 0.51 \\
\cline { 2 - 6 } & value creation & 0.71 & 25.86 & 0.032 & 0.42 \\
\cline { 2 - 6 } & sustainability & 0.64 & 27.42 & 0.47 & 0.55 \\
\hline
\end{tabular}

Table 3. Inter-factor correlations.

\begin{tabular}{|l|c|c|c|c|c|}
\hline \multicolumn{1}{|c|}{ Factors } & Mean & [1] & [2] & [3] & [4] \\
\hline [1] Green practices & 3.65 & 1 & & & \\
\hline [2] Lean management & 3.57 & 0.549 & 1 & & \\
\hline [3] Process innovation & 3.19 & 0.510 & 0.346 & 1 & \\
\hline [4] Green supply chain performance & $35.4 \%$ & 0.208 & 0.181 & 0.219 & 1 \\
\hline
\end{tabular}

The survey instrument was prone to the common method variance (CMV). Most researchers agree that $\mathrm{CMV}$ is a potentially seriously biasing threat. It can lead to wrong conclusions about relationships between variables by inflating or deflating the findings (Craighead et al., 2011). CMV is defined as the amount of spurious correlation between variables that is created by using the same method to measure each variable (Craighead et al., 2011; Richardson et al., 2009). In this study, CFA was used to examine the possibility that common method bias threatened the interpretation of our results. The results showed that all measurement items continued to load on their originally assigned latent variables, suggesting that common method bias was not a serious threat in this study.

The survey was administered across thirteen countries in all regions of the world. In order to verify that respondents completed the questionnaire using the same frame-of-reference and interpreted the rating scale intervals similarly, the measurement equivalence had to be examined. According to Rungtusanatham et al. (2008), ignoring equivalence issues may lead to conclusions that are ambiguous at best and erroneous at worst. Table 4 shows a country specific sample overview of the analyzed and confirmed practices in lean, green, process innovation. The country-specific mean and standard deviation value were listed for all practices. 
Table 4. Measurement equivalence.

\begin{tabular}{|l|c|c|c|}
\hline \multicolumn{1}{|c|}{ Country } & $\begin{array}{c}\text { Lean } \\
\text { practices } \\
\text { (Mean/S.D) }\end{array}$ & $\begin{array}{c}\text { Green Practices } \\
\text { (Mean/S.D) }\end{array}$ & $\begin{array}{c}\text { Process innovation } \\
\text { (Mean/S.D) }\end{array}$ \\
\hline Morocco & $3.57 / 1.15$ & $3.19 / 1.05$ & $3.07 / 1.47$ \\
\hline South of Africa & $3.25 / 1.54$ & $3.84 / 1.32$ & $3.65 / 1.15$ \\
\hline Germany & $3.66 / 1.42$ & $3.47 / 1.06$ & $3.57 / 1.31$ \\
\hline France & $3.05 / 1.27$ & $2.59 / 1.21$ & $3.72 / 1.20$ \\
\hline Italy & $3.74 / 1.36$ & $3.62 / 1.13$ & $3.18 / 1.59$ \\
\hline Spain & $3.00 / 1.50$ & $3.47 / 1.20$ & $3.53 / 1.33$ \\
\hline Sweden & $3.81 / 1.31$ & $3.54 / 1.38$ & $3.80 / 1.32$ \\
\hline Finland & $3.27 / 1.47$ & $4.09 / 1.18$ & $3.79 / 1.20$ \\
\hline USA & $2.96 / 1.33$ & $3.72 / 1.33$ & $3.58 / 1.50$ \\
\hline Austria & $3.38 / 1.24$ & $2.61 / 1.42$ & $4.15 / 1.39$ \\
\hline Brazil & $3.19 / 1.39$ & $3.73 / 1.61$ & $3.62 / 1.43$ \\
\hline Malaysia & $3.42 / 1.13$ & $4.17 / 1.40$ & $3.09 / 1.52$ \\
\hline India & $3.07 / 1.24$ & $3.50 / 1.60$ & $3.97 / 1.36$ \\
\hline
\end{tabular}

\section{Results}

To examine the hypotheses formulated through the review of the literature regarding the relationship and effect of green, lean, and process innovation on Green Supply Chain performance, a series of ordinary least square (OLS) regression analyses were carried out. Prior to performing this analysis, data characteristics for linearity and multicollinearity were tested (Kennedy, 1999). Linearity and equality of variables were tested and confirmed through plotting the standardized residuals against the standardized predicted values. In order to examine multicollinearity, the method proposed by Belsley et al. (1980) was used. Firstly, the variance inflation factors were calculated and analyzed to detect any possible threats, see Table 5. The results obtained confirmed that multicollinearity was not a major problem in this study.

The regression analysis was carried out in two separate frameworks reflecting the two interactions item (i.e. lean and process innovation; green practices and process innovation). In the first step we entered our control variables company size and industry. In the second step lean practices (framework 1) and green practices (framework 2), and process innovation, and the third step the interaction term (framework 1: lean and process innovation; framework 2: green practices and process innovation). 
Table 5. OLS analysis.

\begin{tabular}{|l|c|c|}
\hline & $\begin{array}{c}\text { Framework 1: Lean } \\
\text { practices }\end{array}$ & $\begin{array}{c}\text { Framework 2: Green } \\
\text { practices }\end{array}$ \\
\hline Variable & Std. Estimate & Std. Estimate \\
\hline Control variable & -0.004 & -0.013 \\
\hline Industry & 0.003 & 0.005 \\
\hline Organization size & $0.187^{* *}$ \\
\hline Independent variables & & $0.191^{* *}$ \\
\hline Lean practices & -0.059 & 0.096 \\
\hline Green practices & & \\
\hline Moderator: process innovation & $0.117^{*}$ & $0.095^{*}$ \\
\hline Interactions & 0.012 & 0.011 \\
\hline Lean practices X process innovation & 0.003 & 0.003 \\
\hline Green practices X process innovation & 0.045 & 0.044 \\
\hline Step 1:Adjusted R ${ }^{2} /$ Sig. F change & 0.000 & 0.000 \\
\hline Step 2:Adjusted R ${ }^{2} /$ Sig. F change & 0.048 & 0.047 \\
\hline Step 3:Adjusted R ${ }^{2} /$ Sig. F change & 0.003 & 0.013 \\
\hline Max variance inflation factors & & \\
\hline Notes: ${ }^{*}$ Sign. At the level 0.05; ${ }^{* *}$ Sign. At the level 0.001 & \\
\hline
\end{tabular}

$\mathrm{H}_{1}$ proposed that the implementation of lean management has a significant and positive impact on the performance of green supply chains. The initial results presented in Table 5 showed that implementation of lean practices such as JIT, set-up time reduction, cellular manufacturing, and waste elimination do significantly improve green supply chain performance $(\beta=0.187 ; \mathrm{p}<0.001)$. Our findings are consistent with the previous empirical research which has highlighted that the implementation of lean practices can have a significant effect on green supply chin performance (Martínez-Jurado and Moyano-Fuentes, 2014).

In $\mathrm{H}_{2}$ it was hypothesized that the implementation of green practices have a significant and positive impact on green supply chain performance. The results presented in Table 5 showed that, as expected, the adoption of green practices such as eco-design and life cycle assessment, green manufacturing, reverse logistics, and waste management do significantly improve green supply chain performance $(\beta=0.191 ; \mathrm{p}<0.001)$. Therefore, the results confirmed the suggestions and findings of previous literature regarding the positive relationship between green practices and green supply chain performance (Zhang et al. 2012; Vinodh et al., 2011).

$\mathrm{H}_{3}$ assumed that the adoption of process innovation has a significant and positive impact on green supply chain performance. Previous literature on process innovation has suggested that this type of innovation activity is a comprehensive and systematic mechanism to improve 
different performances (Brem et al., 2016; Salerno et al., 2015; Zailani et al., 2015; Lau et al., 2010; Lambertini and Mantovani, 2009). However, contrary to this, the results obtained from our analysis and presented in Table 5 showed that the adoption of process innovation practices do not improve green supply chain performance.

In the final hypothesis, it was suggested that the implementation of lean and green practices have a stronger positive impact on green supply chain performance when combined with the adoption of process innovation. To study these potential synergetic effects, interaction terms were calculated, modelling process innovation as the modeling variable. In this context, $\mathrm{H}_{4 a}$ tested the synergetic effects between process innovation and lean practices. Adding the two way interaction to the OLS Framework 1 contributed to a significant change in the variance explained ( $\mathrm{R}^{2}$ adj: 0.048, $\left.\mathrm{p}=0.003\right)$, and the interaction terms was significant $(\beta$ $=0.117, \mathrm{p}<0.001)$. To interpret this finding, the significance of the slopes was calculated at low and high levels of process innovation. The results showed that the implementation of lean practices were more strongly associated with green supply chain performance when the adoption of process innovation were high $(\beta=0.28 ; \mathrm{p}<0.001)$ than when process innovation were low $(\beta=0.17 ; \mathrm{p}<0.05)$. In other words, this suggested that the implementation of lean practices does have a higher payoff rate in terms of green supply chain performance when the firm is also adopting process innovation. In this perspective, it is concluded that there is a synergetic effect between process innovation and lean practices.

$\mathrm{H}_{4 b}$ was formulated to investigate the synergetic effects between process innovation and green practices. Adding the two way interaction to the OLS Framework 2 contributed to a significant change in the variance explained $\left(\mathrm{R}^{2}\right.$ adj: 0.047, $\left.\mathrm{p}=0.013\right)$, and the interaction terms was significant $(\beta=0.095, \mathrm{p}<0.05)$. To interpret this finding, the significance of the slopes was calculated at low and high levels of process innovation. The results showed that the implementation of green practices was more strongly associated with green supply chain performance when adoption of process innovation were high $(\beta=0.29 ; \mathrm{p}<0.001)$ than when process innovation were low $(\beta=0.15 ; \mathrm{p}<0.05)$. This indicated that the implementation of green practices does have a higher effect in terms of green supply chain performance when the firm is also adopting process innovation. In this perspective, it is concluded that there is a synergetic effect between process innovation and green practices. 


\section{Discussion of results}

\subsection{Effect of lean practices on GSCs performance $\left(H_{1}\right)$}

The results of the analyzes suggested that the adoption of lean practices such as JIT, set-up time reduction, cellular manufacturing, and waste elimination can significantly contribute to the improvement of the performance of GSCs, see Table 5. This in line with the wide amount of evidence found in the academic literature which suggests that LM may act as an effective catalyst and approach to tackle some of the fundamental environmental and sustainability challenges currently faced by organizations and their supply chains (Cherrafi et al., 2016a; Martínez-Jurado and Moyano-Fuentes, 2014; Dües et al., 2013; Mollenkopf et al., 2010). The positive effect of LM on GSC performance may be partially explained due to the ability of its JIT, set-up time reduction, cellular manufacturing and waste reduction practices to lessen inventory levels, excess capacity, and transport and production times (Carvalho et al. 2017; Carvalho et al., 2011). For instance, it is well established in the academic literature that a JIT system, enabled by manufacturing cells and the reduction of set-up time and waste, has a significant positive effect on the reduction of inventory, which exposes problems (Belekoukias et al., 2014; Cua et al., 2006). Subsequently, the consumption of material is reduced through better quality that is achieved by eliminating the exposed problems from the root cause, and in this way eliminating/reducing wastes such as scrap and rework (Shingo, 1989). In addition, following the JIT's advice of having smaller deliveries, smaller vehicles can be utilised, resulting in less fuel consumption and $\mathrm{CO}_{2}$ emissions (Garza-Reyes et al., 2016; Sarkis, 2001). Similarly, since JIT, set-up time reduction, cellular manufacturing, and waste elimination will reduce inventory, the energy required to safely store it will also be reduced (Franchetti et al., 2009). Finally, according to Chiarini (2014), by grouping in a single cell machines, staff, and workplaces dedicated to similar products, the transportation of material can be greatly reduced; resulting in a significant reduction of energy consumption of electric vehicles used to move material. In summary, all this evidence intends to explain how LM, through some of its most common practices such as JIT, set-up time reduction, cellular manufacturing, and waste elimination, can have a positive effect on the reduction of material consumption, waste and energy consumption. These benefits will ultimately go beyond a company's internal operations to also be experienced in their supply chain operations, ultimately contributing to improve their green performance. This is aligned to the results obtained in this study, which also reinforce the idea that sustainability may be considered the next evolutionary step of LM as suggested by Govindan et al. (2014a) and Fliedner and Majeske (2010). 


\subsection{Effect of green practices on GSCs performance $\left(\mathrm{H}_{2}\right)$}

In terms of the effect of green practices such as eco-design and life cycle assessment, green manufacturing, reverse logistics, and waste management, the results of this study indicated that they have a significant positive effect on GSC performance, see Table 5. Since these green practices' main focus is the reduction of the environmental negative impacts of companies' products/services and operations (Garza-Reyes, 2016b) at either product/service, organizational or supply chain levels, their synergy with GSC performance seems logical. Reduction of material consumption, transportation, production resources and hence the minimization of energy and emissions are benefits of these practices (Pagell and Gobeli, 2009; Svensson, 2007, Pagell et al., 2004; Christmann, 2000; Russo and Fouts, 1997) closely associated to the principles and objectives of GSCs. Thus, the results obtained from this research do not only support the logically implicit synergy between green practices and GSC performance, but also that established in the academic literature by authors such as Zhang et al. (2012) and Vinodh et al. (2011). This suggests that organizations that wish to improve the 'greenness level' of their supply chain can consider the adoption of practices including ecodesign and life cycle assessment, green manufacturing, reverse logistics, and waste management as a catalyst to achieve this endeavor.

\subsection{Effect of process innovation on GSCs performance $\left(\mathrm{H}_{3}\right)$}

The academic literature shows a wide consensus regarding the positive effect of process innovation on different types of organizational performance that include customer satisfaction, operational performance, financial performance, and competitive advantage (Brem et al., 2016; Salerno et al., 2015; Zailani et al., 2015; Lau et al., 2010; Lambertini and Mantovani, 2009). However, the results of this study indicate that the adoption of process innovation practices such as (1) fast response to the new processes introduced by other companies within the same sector, (2) pioneering disposition to introduced new process, and (3) number of changes in the process introduced in one year, do not have a direct contribution to the improvement of GSC performance, see Table 5. A possible explanation for this may be the fact that all these process innovation activities take place, and are adopted, primarily at a firm level, for which their effect on the performance of the wider supply chain of firms may not be strongly felt. Nevertheless, the success of some specific process innovation activities, for example, those involving product design practices, is crucially dependent upon the 
alignment with corresponding supply chain configurations. For example, Pero et al. (2010) and Van Hoek and Chapman (2007) indicate the need for aligning product design and supply chain management and design. This may suggest a stronger and direct effect of this specific process innovation practice on the performance of GSCs. Therefore, although an indirect positive effect between process innovation and GSC performance was found to actually exists, see following section regarding $\mathrm{H}_{4}$, further studies need to be conducted to determine whether process innovation positively and directly affects GSC performance. Additionally, since the results of this study contradict those of the previous academic literature, a suggestion to perform further studies in relation to this aspect is recommended as part of a future research agenda to validate the results of this study and advance knowledge in this subject area.

\subsection{Combined effect of lean/green practices and process innovation on GSCs performance $\left(\mathrm{H}_{4}\right)$}

Despite the results of this study indicated that process innovation does not have a direct positive effect on GSC performance $\left(\mathrm{H}_{3}\right)$, further results $\left(\mathrm{H}_{4}\right)$ also suggested that process innovation has an 'amplifying' (i.e. enhancing) effect which contributes to lean and green practices to offer a higher payoff rate in terms of green supply chain performance when these are coupled with process innovation activities. Thus, it was concluded that there is a synergetic positive effect between process innovation and lean/green practices, where the first enhances the former. Due to the lack of previous studies in the academic literature exploring the relationship between process innovation and lean/green practices and their effect on GSC performance, it is not possible to establish an alignment, or misalignment, of these results to the academic theory. However, since it has been previously established that lean fosters innovation, including process innovation (He et al., 2015; Antony et al., 2012), the synergetic positive effect between process innovation and lean/green practices and their positive impact on GSC performance can be considered aligned to this principle and findings. Due to their nature and current maturity, LM and green practices may be substitutable and transferable across organizations and supply chains. However, when these are adopted in a company's processes innovatively and in a way in which such adoption is rare and difficult to imitate, then the benefits and payoffs of lean and green practices may be magnified. This magnified lean/green positive effect will not only be felt within the internal company's operations but also throughout its supply chain operations as indicated in the academic literature (Carvalho et al., 2017; Martínez-Jurado et al., 2014; Hajmohammad et al., 2013) and as established by the results of this study obtained when testing $\mathrm{H}_{3}$ and $\mathrm{H}_{4}$. These conditions may explain some of 
the reasons of the magnifying effect created by process innovation on the effect of LM and green practices on the positive performance of GSCs.

\section{Concluding remarks, limitations and future research directions}

This paper investigates the casual relationships between LM, green practices and process innovation, and their impact on the performance of GSCs. To do this, the study proposes a framework to model and establish such relationships based on some of the most common lean, green, process innovation and GSC practices, see Table 2. Consequently, this study fills a research gap as previously established in Sections 1 and 2, and extends our knowledge in the sustainability, lean management, innovation and supply chain management fields by:

- Exploring and helping us to understand the effect that LM, green and process innovation practices have on the performance of GSCs;

- Investigating and establishing the synergetic relationship between LM, green and process innovation practices, and their combined effect on GSC performance; and

- Quantifying and explaining the given relationships and effects.

These contributions are relevant to the theory of the aforementioned fields as green lean, process innovation, and supply chain sustainability have been extensively investigated, but mainly treated as independent research subjects. Combining these subjects as part of the same research stream is a challenge and the originality of this research.

Similarly, the contributions of this study are equally relevant within the industrial context, especially for supply chain and operations managers who aim to gain a better understanding of the relationship and effect of contemporary operational practices on the green performance of their supply chains. In particular, the lack of a clear understanding and knowledge of the relationship between LM, green and process innovation on the performance of GSCs may create an obstacle for these managers, and their organizations, to justify the implementation of GSCs. In addition, the insight of the relationships and effects of these practices provided by this study can also assist managers to take better decisions and formulate appropriate strategies for effectively developing and/or adopting GSC practices within their organizations. This will help their companies to not only improve profitability but also contribute to tackle some of the major sustainability challenges currently faced by humankind and comply with governmental environmental regulations. 
Although this study was conducted within the context of the manufacturing sector, other industrial segments such as services, grocery, healthcare, logistics and transport, among others, can also benefit from this research and the results derived from it. Similarly as the manufacturing industry, all these other sectors are also under increasing pressure to become more sustainable in their supply chains and internal operations. The effective implementation of a GSC, enhanced by the simultaneous adoption of LM, green and process innovation practices can provide them with the opportunity to achieve this venture. In a similar manner, this study may encourage organizations not currently embarked on, or fully committed to, sustainability, but devoted to the adoption and sustainment of operations improvement approaches such as lean or process innovation to contemplate the synergies and benefits they can bring to make their supply chains and operations more sustainable.

In terms of research limitations, this study was restricted by various confining factors which constrained the scope and extent of the research and it results. These are essential to be highlighted to be considered in future studies and to guide the direction of the future research agenda. Firstly, this research was conducted within the context of the manufacturing sector only. This presents an opportunity to gain added insights into the relationship of LM, green and process innovation practices and their effect on the GSCs performance of companies operating in order business sectors. This can provide further light into the effect and role that specific industry characteristics can have on the relationships of the studied practices and their impact on the performance of GSCs. Secondly, due to the quantitative nature and strategy followed in this research to collect data by using a survey instrument based on a Likert-style rating, the present study suffers from the limited ability of the respondents to express their views and opinions other than those pre-set as answers. This limitation can be overcome in future researches by also conducting qualitative interviews with some selected organizations. This strategy will also contribute in gaining further validation of the results obtained. Finally, since the research was only focused on industrial experts, it omitted the views of academic experts. Thus, besides considering pragmatic sources only, future studies can also be underpinned by academic and research experts in the field. This will ensure that theoretical dimensions of the research are also included and considered as part of the research, which will derive in an improved robustness of the study 


\section{References}

Anderson, J.C. and Gerbing, D.W., 1988. Structural equation modeling in practice: a review and recommended two-step approach. Psychological Bulletin, 103 (3), 411-23.

Arkader, R., 2001. The perspective of suppliers on lean supply in a developing country context. Integrated Manufacturing System ,12 (2), 87-94.

Azevedo, S.G., Carvalho, H., Duarte, S., \& Cruz-Machado, V., 2012. Influence of Green and Lean Upstream Supply Chain Management Practices on Business Sustainability. IEEE Transactions on Engineering Management, 59 (4), 753-765.

Barney, J., 1991. Firm resources and sustained competitive advantage. Journal of Management, 17 (1), 99-120.

Beckmann, M., Hielscher, S., \& Pies, I., 2014. Commitment Strategies for Sustainability: How Business Firms Can Transform Trade-Offs Into Win-Win Outcomes. Business Strategy and the Environment, 23(1), 18-37.

Belekoukias, I., Garza-Reyes, J.A., Kumar, V., 2014. The impact of lean methods and tools on the operational performance of manufacturing organisations. International Journal of Production Research, 52(18), 5346-5366.

Belsley, D.A., Kuh, E. and Welsch, R.E. 1980. Regression Diagnostics, John Wiley \& Sons, New York, NY.

Brem, A. Nylund, P.A., Schuster, G., 2016. Innovation and de facto standardization: The influence of dominant design on innovative performance, radical innovation, and process innovation. Technovation. (50-51), 79-88.

Berrone, P., Fosfuri, A., Gelabert, L., \& Gomez-Mejia, L. R. 2013. Necessity as the mother of 'green' inventions: Institutional pressures and environmental innovations. Strategic Management Journal, 34(8), 891-909.

Beske, P., 2012. NOFOMA dynamic capabilities and sustainable supply chain management. International Journal of Physical Distribution \& Logistics Management, 42 (4), 5-25.

Carvalho, H., Duarte, S., Cruz-Machado, V., 2011. Lean, agile, resilient and green: divergences and synergies. International Journal of Lean Six Sigma, 2(2), 151-179.

Carvalho, H., Govindan, K, Azevedo, S.G., Cruz-Machado, V., 2017. Modelling green and lean supply chains: An eco-efficiency perspective. Resources, Conservation and Recycling, DOI: http://dx.doi.org/10.1016/j.resconrec.2016.09.025 (in press).

Chiarini, A., 2014. Sustainable manufacturing-greening processes using specific lean production tools: an empirical observation from European motorcycle component manufacturers. Journal of Cleaner Production, 85, 226-233.

Chen, Y., Lai, S., Wen, C., 2006. The influence of green innovation performance on corporate advantage in Taiwan. Journal of Business Ethics, 67, 331-339.

Cherrafi, A., Elfezazi, S., Chiarini, A., Mokhlis, A., Benhida, K., 2016a. The integration of lean manufacturing, Six Sigma and sustainability: a literature review and future research directions for developing a specific model. Journal of Cleaner Production, 139, 828 846.

Cherrafi, A., Elfezazi, S., Govindan, K., Garza-Reyes, J.A., Benhida, K., Mokhlis, A., 2016b. Development of framework for integrating Green and Lean Six Sigma. International Journal of Production Research, DO (http://dx.doi.org/10.1080/00207543.2016.1266406) (in press).

Chiou, T.-Y., Chan, H.K., Lettice, F., Chung, S.H., 2011. The influence of greening the suppliers and green innovation on environmental performance and competitive advantage in Taiwan. Transp. Res. Part E Logist. Transp. Rev. 47, 822-836. 
Christmann, P., 2000. Effects of 'best practices' of environmental management on cost advantage: the role of complimentary assets. Academy of Management Journal, 43 (4), 663-80.

Craighead, C.W, Ketchen, D.J., Kaitlin, Jr., Dunn, S., and Hult, G., 2011. Addressing Common Method Variance: Guidelines for Survey Research on Information Technology, Operations, and Supply Chain Management. IEEE transactions on engineering management, 58 (3), 578-588.

Cua, K.O., McKone-Sweet, K.E., Schroeder, R.G., 2006. Improving Performance through an Integrated Manufacturing Program. Quality Management Journal, 13(3), 45-60.

Dahlgaard, J.J. Dahlgaard-Park, D.M., 2006. Lean production, Six Sigma quality, TQM and company culture. TQM Mag. 18(3), 263-281.

Dennis, P., 2007. Lean production simplified. New York: Productivity Press.

Doran, J. and Ryan, G., 2012. Regulation and firm perception, eco-innovation and firm performance. Eur. J. Innov. Manag. 15(4):421-441.

Dou, Y., Zhu, Q. and Sarkis, J., 2013. Evaluating Green Supplier Development Programs with a Grey-Analytical Network Process-based Methodology. European Journal of Operational Research, 233(2), 420-431.

Dubey, R., Gunasekaran, A., \& Ali, S. S., 2015. Exploring the relationship between leadership, operational practices, institutional pressures and environmental performance: A framework for green supply chain. International Journal of Production Economics, 160,120-132.

Dües, C.M., Tan, K.H., Lim, M., 2013. Green as the new lean: how to use lean practices as a catalyst to greening your supply chain. Journal of Cleaner Production. 40, 93-100.

EPA, 2009. The Environmental Professional's Guide to Lean and Six Sigma. www.epa.gov/lean/ (accessed 24 December 2016).

Fliedner, G., Majeske, K., 2010. Sustainability: the new lean frontier. Prod. Inventory Manage. J. 46 (1), 6-13.

Florida, R., 1996. Lean and Green: The move to environmentally conscious manufacturing. California Bus. Rev. 39(1), 80-105.

Franchetti, M., Bedal, K., Ulloa, J., Grodek, S., 2009. Lean and green: industrial engineering methods are natural stepping stones to green Engineering. Industrial Engineer. 41(9), 24-29.

Gao, D., Xu, Z., Ruan, Y.Z., Lu, H., 2017. From a systematic literature review to integrated definition for sustainable supply chain innovation (SSCI), Journal of Cleaner Production, 142 (4), 20 1518-1538.

Garza-Reyes, J.A., 2015a. Lean and Green - A systematic review of the state of the art literature. Journal of Cleaner Production. 102, 18-29.

Garza-Reyes, J.A., 2015b. Green lean and the need for Six Sigma. International Journal of Lean Six Sigma. 6(3), 226-248.

Govindan, K., Azevedo, S.G., Carvalho, H., Cruz -Machado, V., 2014a. Impact of supply chain management practices on sustainability. Journal of Cleaner Production, 85, 212225.

Govindan, K., Kaliyan, M., Kannan, D., Haq, A., 2014b. Barriers analysis for green supply chain management implementation in Indian industries using analytic hierarchy process. International Journal of Production Economics, 147, 555-568. 
Govindan, K., Sarkis, J., Chiappetta Jabbour, C.J., Zhu, Q., Geng, Y., 2014c. Eco-efficiency based green supply chain management: current status and opportunities. European Journal of Operational Research 233(2), 293-298.

Grant, R.M., 1991. The resource-based theory of competitive advantage: implications for strategy formulation. California Management Review, 33 (3), 114-135.

Hajmohammad, S., Vachon, S., Klassen, R.D., Gavronski, I., 2013. Lean management and supply management: their role in green practices and performance. J. Clean. Prod. 39, 312-320.

Halme, M., Park, J. and Chiu, A. (2002), "Managing globalization for sustainability in the 21SI Century. Journal of Business Strategy and Environment, 11 (2), 81-89.

He, Z., Deng, Y., Zhan, M., Zu, X., Antony, J., 2015. An empirical investigation of the relationship between Six Sigma practices and organisational innovation. TQM \& Business Excellence. DOI: http://dx.doi.org/10.1080/14783363.2015.1092866 (in press).

Hines, P., 1996. Purchasing for lean production: the new strategic agenda. Int. J. Purchasing Mater. Manage. 32 (1), 2-10.

Hines, R., Holweg, M. Rich, N., 2004. Learning to evolve: a review of contemporary lean thinking. Int. J. Operat. Prod. Manag. 24(10), 994-1011.

Hojnik, J., Ruzzier, M., (2016). The driving forces of process eco-innovation and its impact on performance: Insights from Slovenia. Journal of Cleaner Production, 133, 812-825.

$\mathrm{Hu}, \mathrm{L}$. and Bentler, P.M., 1998. Fit indices in covariance structure modelling: sensitivity to under-parameterized model misspecification. Psychological Methods, 3 (4), 424-53.

Jabbour, C.J.C., Neto, A.S., Gobbo Jr., J.A., Ribeiro, M.S. and Jabbour, A.B.L.S., 2015. Ecoinnovations in more sustainable supply chains for a low-carbon economy: A multiple case study of human critical success factors in Brazilian leading companies. International Journal of Production Economics, 164, 245-257.

Jayal, A.D., Badurdeen,F., Dillon Jr., O.W., Jawahir, I.S., 2010. Sustainable manufacturing: modeling and optimization challenges at the product, process and system levels. CIRP J. Manuf. Sci. Technol. 2, 144-152.

Kammerer, D., 2009. The effects of customer benefit and regulation on environmental product innovation. Empirical evidence from appliance manufacturers in Germany. Ecological Economics 68, 2285-2295.

Kennedy, P., 1999. A Guide to Econometrics, Blackwell Publishers, Oxford.

Kibbelling, M., van der Bij, H., van Weele, A., 2013. Market orientation andinnovativeness in supply chains: supplier's impact on customer satisfaction. J.Prod. Innov. Manag. 30 (3), 500-515.

Kleindorfer, P.R., Singhal, K., van Wassenhove, L.N., 2005. Sustainable operations management. Production and Operations Management 14 (4), 482-492.

Kline, R.B., 1998. Principles and Practice of Structural Equation Modeling, The Guilford Press New York, NY.

Kolk, A., Pinkse, J., 2004. Market strategies for climate change. European Management Journal, 22(3), 304-314.

Lambertini, L., Mantovani, A., 2009. Process and product innovation by a multiproduct monopolist: a dynamic approach. International Journal of Industrial Organization, 27 (4), 508-518. 
Lau, A.K.W., Tang, E., Yam, R.C.M., 2010. Effects of supplier and customer integration on product innovation and performance: Empirical evidence in Hong Kong manufacturers. Journal of Product Innovation Management, 27 (5), 761-777.

Lee, S.Y., 2012. Corporate carbon strategies in responding to climate change. Business Strategy and the Environment, 21(1), 33- 48.

Lee, V.-H., Ooi, K.-B., Chong, A. Y.-L., \& Seow, C., 2014. Creating technological innovation via green supply chain management: An empirical analysis. Expert Systems with Applications, 41, 6983-6994.

Lii, P. and Kuo, F.-I., 2016. Innovation-oriented supply chain integration for combined competitiveness and firm performance. International Journal of Production Economics, $174,142-155$.

Liker, J.K., 1996. Becoming Lean. New York: Free Press.

Luthra, S., Garg, D., Haleem, A., 2016. The impacts of critical success factors for implementing green supply chain management towards sustainability: An empirical investigation of Indian automobile industry, Journal of Cleaner Production, 121, 142158.

Martínez-Jurado, P., Moyano-Fuentes, J. (2014). Lean Management, Supply Chain Management and Sustainability: A Literature Review, Journal of Cleaner Production, 85, 134-150.

Martínez-Jurado, P., Moyano-Fuentes, J. and Jerez-Gómez, P. (2014). Human resource management in lean production adoption and implementation process: success factors in the aeronautics industry, Business Research Quarterly, 17(1), 47-68.

Mason, R., Nieuwenhuis, P., Simons, D., 2008. Lean and green supply chain mapping: adapting a lean management tool to the needs of industrial ecology. Prog. Ind. Ecol. Int. J. 5 (4), 302-324.

Meeus, M.T.H., Edquist, C., 2006. Introduction to part 1: product and process innovation. In Hage, J., Meeus, M.T.H. (Eds). Innovation, Science and Institutional Change, pp. 1-37. Oxford: Oxford University Press.

Mollenkopf, D., Stolze, H., Tate, W., Ueltschy, M., 2010. Green, lean, and global supply chains. Int. J. Phys. Distrib. Logist. Manag. 40(1/2), 14-41.

Moyano-Fuentes, J., Sacristán-Díaz, M., 2012. Learning on lean: a review of thinking and research. Int. J. Operations Prod. Manage. 32 (5), 551-582.

Mu, J., Peng, G., MacLachlan, D.L., 2009. Effect of risk management strategy on NPD performance. Technovation, 29 (3), 170-180.

Murillo-Luna, J. L., Garcés-Ayerbe, C., \& Rivera-Torres, P. 2008. Why do patterns of environmental response differ? A stakeholders' pressure approach. Strategic Management Journal, 29(11): 1225-1240.

Nieto, M.J., Santamaría, L., 2007. The importance of diverse collaborative networksfor novelty of product innovation. Technovation, 27, 367-377.

Nunnally, J.C., 1978. Psychometric Theory, McGraw Hill, New York, NY.

Onofrei, G., Eamonn, A., Wiengarten, F., Fynes, B., 2016. The interplay between environmental and quality/lean practices in Supply Chains.In book: Joining Complexity Science and Social Simulation for Innovation Policy: Agent-based modelling using the SKIN platform, Edition: 1, Publisher: Cambridge Press, Editors: Petra Ahrweiler, Nigel Gilbert, Andreas Pyka, 76-108. 
Pagell, M., 2004. Understanding the factors that enable and inhibit the integration of operations, purchasing and logistics. Journal of Operations Management, 22 (5), 459487.

Pagell, M. and Gobeli, D., 2009. How plant managers' experiences and attitudes towards sustainability relate to operational performance. Production and Operations Management Journal, 18 (3), 278-99.

Pagell, M., Yang, C., Krumwiede, D.K. and Sheu, C., 2004. Does the competitive environment influence the efficacy of investments in environmental management?. Journal of Supply Chain Management, 40 (3), 30-9.

Pan, X., Li, S., 2016. Dynamic optimal control of process- product innovation with learning by doing, European Journal of Operational Research, 248 (1), 136-145.

Peirchyi, Lii and Fang-I. Kuo, Innovation-oriented supply chain integration for combined competitiveness and firm performance. International Journal of Production Economics, $174,142-155$.

Peng, X., Liu, Y., (2016). Behind eco-innovation: Managerial environmental awareness and external resource acquisition. Journal of Cleaner Production, 139, 347-360.

Peng, Y.-S., Lin, S.-S., 2008. Local responsiveness pressure, subsidiary resources, green management adoption and subsidiary's performance: Evidence from Taiwanese manufactures. Journal of Business Ethics. 79 (1-2), 199-212.

Pérez, C., de Castro, R., Simons, D., Giménez, G., 2010. Development of lean supply chains: a case study of the Catalan pork sector. Supply Chain Manag. Int. J. 15(1), 55-68.

Pero, M., Abdelkafi, N., Sianesi, A., Blecker, T., 2010. A framework for the alignment of new product development and supply chains. Supply Chain Management: An International Journal. 15(2), 115-128.

Peteraf, M.A., 1993. The cornerstones of competitive advantage: a resource-based view. Strategic Management Journal, 14 (3), 179-191.

Presley, A., Meade, L., Sarkis, J., 2007. A strategic sustainability justification methodology for organizational decisions: a reverse logistics illustration. International Journal of Production Research 45 (18-19), 4595-4620.

Purba, R., Diane, H., 2005. Do green supply chains lead to competitiveness and economic performance? International Journal of Operations \& Production Management, 25 (9), 898-916.

Qi, G. Y., Shen, L. Y., Zeng, S. X., \& Jorge, O. J., 2010. The drivers for contractors' green innovation: an industry perspective. Journal of Cleaner Production, 18(14): 1358-1365.

Rennings, K., Ziegler, A., Ankele, K., Hoffmann, E., 2006. The influence of different characteristics of the EU environmental management and auditing scheme on technical environmental innovations and economic performance. Ecol. Econ. 57, 45-59.

Richardson, H. A., Simmering, M. J. and Sturman, M. C., 2009. A tale of three perspectives: Examining post hoc statistical techniques for detection and correction of common method variance. Organizational Res. Methods, 12 (4), 762-800.

Rungtusanatham, M., Ng, C. H., Zhao, X., and Lee, T.S., 2008. Pooling data across transparently different groups of key informants: measurement equivalence and survey research. Decision Sciences, 39 (1), 115-145.

Russell, R.S., Taylor, B.W., 2000. Operations Management. Prentice-Hall, Englewood Cliffs.

Russo, M.V., Fouts, P.A., 1997. A resource-based perspective on corporate environmental performance and profitability. Acad. Manag. J. 40(3), 534-559. 
Salerno, M.S., de Vasconcelos Gomes, L.A., Oliveira da Silva, D., Barros Bagno, R., Uchôa Freitas, S.L.T., 2015. Innovation processes: Which process for which project?. Technovation, 35, 59-70.

Sarkis, J., 2001. Manufacturing's role in corporate environmental sustainability: concerns for the new millennium. International Journal of Operations and Production Management. 21(5/6), 666-686.

Scur, G., Barbosa, M.E., 2017. Green supply chain management practices: Multiple case studies in the Brazilian home appliance industry, Journal of Cleaner Production, 141, 1293-1302.

Shingo, S., 1989. A Study of Toyota Production System: from an Industrial Engineering Viewpoint. Productivity Press, NY.

Simpson, D.F, Power, D.J., 2005. Use the supply relationship to develop lean and green suppliers. Supply Chain Manag. An Int. J. 10(1), 60-68.

So, S.C.K., Sun, H.Y., 2010. Supplier integration strategy for lean manufacturing adoption in electronic-enabled supply chains. Supply Chain Manag. Int. J. 15 (6),474-487.

Soosay, C.A., Hyland, P.W., Ferrer, M., 2008. Supply chain collaboration: capabilities for continuous innovation. Supply Chain Manag. Int. J. 13, 160-169.

Sprengel D., Busch T., 2011. Stakeholder engagement and environmental strategy - the case of climate change. Business Strategy and the Environment, 20(6), 351-364.

Srivastava, S.K., 2007. Green supply chain management: A state-of-the art literature view. Int. J. Manage. Rev. 9(1), 53-80.

Svensson, G., 2007. Aspects of sustainable supply chain management (SSCM): conceptual framework and empirical example", Supply Chain Management: An International Journal, 12 (4), 262-266.

Teece, D.J., 1986. Firm boundaries, technological innovation and strategic planning, in Thomas, G.L. (Ed.), The Economics of Strategic Planning, D.C., Heath, Lexington, MA, 187-99.

Thong, J. Y. L., 2001. Resource constraints and information systems implementation in Singaporean small businesses. Omega, 29, 143-156.

Vachon, S., Klassen, R.D., 2006. Extending green practices across the supply chain: the impact of upstream and downstream integration. Int. J. Oper. Prod. Manag. 26, 795-821.

Van Hoek, R., Chapman, P., 2007. How to move supply chain beyond cleaning up after new product development. Supply Chain Management: An International Journal, 12(4), 239244.

Van Vuuren, D.P., Den Elzen, M.G.J., Lucas, P.L., Eickhout, B., Strengers, B.J., Van Ruijven, B., Wonink, S. And Houdt, R.V., 2007. Stabilizing greenhouse gas concentrations at low levels: an assessment of reduction strategies and costs. Climatic Change, 81, 119-159.

Weinhofer, G., Hoffmann, V.H., 2010. Mitigating climate change - how do corporate strategies differ? Business Strategy and the Environment, 19(2), 77-89.

Womack, J.P., Jones, D.T., Ross, D., 1990. The Machine that Changed the World. Rawson Associates, New York.

Wong, Y.P., Tseng, M.L., Tan, K., 2013. A business process management capabilities perspective on organization performance. Total Quality Management \& Business Excellence, 25 (6), 602-617. 
Zailani, S., Govindan, K., Iranmanesh, M., Shaharudin, M.R., 2015. Green Innovation Adoption in Automotive Supply Chain: The Malaysian case. Journal of Cleaner Production, 108 (A), 1115-1122. doi:10.1016/j.jclepro.2015.06.039

Zhang, J.J., Joglekar, N.R., \& Verma, R., 2012. Exploring resource efficiency bench- marks for environmental sustainability in hotels. Cornell Hospitality Quarterly, 53 (3), 229 241.

Zhao, X. \& Sun, B., 2016. The influence of Chinese environmental regulation on corporation innovation and competitiveness. Journal of Cleaner Production, 112(Part 2), 15281536.

Zhu, Q., Sarkis, J., 2004. Relationships between operational practices and performance among early adopters of green supply chain management practices in Chinese manufacturing enterprises. Journal of Operations Management, 22(3), 265-289.

Zimmermann, R., Miguel, L., Fernandes, D., Antonio, F., Moreira, C., 2016. The influence of supply chain on the innovation process: a systematic literature review. Supply Chain Management: An International Journal, 21 (3), 289 - 304. 